\title{
Effect of methanol extracts of rosemary and olive vegetable water on the stability of olive oil and sunflower oil
}

\author{
By T.H. Gamel ${ }^{a}$ and A. Kiritsakis ${ }^{\text {tb }}$ \\ a Department of Food Technology, Faculty of Agriculture, Alexandria University, Egypt. \\ b Department of Food Technology, Technological Educational Institution, Thessaloniki, Greece.
}

\section{RESUMEN}

Efecto de extractos metanólicos de romero y del agua de vegetación de la aceituna sobre la estabilidad del aceite de oliva y del aceite de girasol.

Extractos metanólicos de fenoles de hojas secas de romero y filtrados de agua de vegetación de la aceituna, en combinación con BHA, se añadieron al aceite de oliva (mezcla de aceite de oliva refinado y virgen, 3 a 1) y al aceite de girasol, evaluándose sus efectos antioxidantes usando condiciones aceleradas. Estas condiciones incluyeron el test del horno de oxidación $\left(a 63^{\circ} \mathrm{C}\right)$ y el método de conductividad (Rancimat a $120^{\circ} \mathrm{C}$ ). También se aplicó al proceso de fritura a $180^{\circ} \mathrm{C}$. Los extractos metanólicos de fenoles y el BHA se añadieron a cada aceite en las siguientes concentraciones: $200 \mathrm{ppm}$ de extracto de romero, $200 \mathrm{ppm}$ de extracto de agua de vegetación de la aceituna, 100 ppm de extracto de romero + 100 ppm de BHA, $100 \mathrm{ppm}$ de extracto de agua de vegetación +100 ppm de BHA y 200 ppm de BHA. En general, el efecto antioxidante de los aditivos fenólicos de romero y de BHA tuvo el siguiente orden: $200 \mathrm{ppm}$ de extracto de romero $>100 \mathrm{ppm}$ de extracto de romero + $100 \mathrm{ppm}$ de $\mathrm{BHA}>$ y $200 \mathrm{ppm}$ de BHA. La adición de 200 ppm de extracto de agua de vegetación y 100 ppm de extracto de agua de vegetación + 100 ppm de BHA mostró un efecto antioxidante similar al de $200 \mathrm{ppm}$ de BHA.

PALABRAS-CLAVE: Aceite de girasol - Aceite de oliva - Agua de vegetación de la aceituna - Efecto antioxidante - Estabilidad Romero.

\section{SUMMARY}

Effect $o_{1}$ meinanol extracts of rosemary and olive vegetable water on the stability of olive oil and sunflower oil.

Methanol phenolic extracts of dry rosemary leaves and olive vegetable water filtrate, in combination with $\mathrm{BHA}$, were added to olive oil (blend of refined and virgin olive oil, 3 to 1 ) and to sunflower oil and their antioxidant effects under accelerated conditions were evaluated. Accelerated conditions included the oven test (at $63^{\circ} \mathrm{C}$ ) and the conductivity method (Rancimat at $120^{\circ} \mathrm{C}$ ). Frying process at $180^{\circ} \mathrm{C}$ was also applied. The methanol phenolic extracts and the $\mathrm{BHA}$ were added to each oil at the following concentrations: $200 \mathrm{ppm}$ rosemary extract; $200 \mathrm{ppm}$ olive vegetable water extract; $100 \mathrm{ppm}$ rosemary extract $+100 \mathrm{ppm} \mathrm{BHA;} 100 \mathrm{ppm}$ vegetable water extract $+100 \mathrm{ppm}$ BHA and $200 \mathrm{ppm}$ BHA. In general, antioxidant effect of phenolic additives of rosemary and of BHAwas in the following order: $200 \mathrm{ppm}$ rosemary extract $>100 \mathrm{ppm}$ rosemary extract $+100 \mathrm{ppm} \mathrm{BHA}>$ and $200 \mathrm{ppm}$ BHA. The addition of $200 \mathrm{ppm}$ vegetable water extract and $100 \mathrm{ppm}$ vegetable water extract $+100 \mathrm{ppm}$ BHA exhibited similar antioxidant effect to that of $200 \mathrm{ppm}$ BHA.

KEY-WORDS: Antioxidant effect - Olive oil - Olive vegetable water - Rosemary - Stability - Sunflower oil.

\section{INTRODUCTION}

Natural and synthetic antioxidants are used to delay or to retard the oxidative deterioration of fats and oils. The major food antioxidants are phenolic compounds and are generally referred to as phenolic antioxidants (Sherwin, 1990). Recently, consumers show a growing tendency to reject all synthetic additives to foods, including synthetic antioxidants. Thus, there has been an increased interest on the use of natural antioxidants, especially those extracted from herbs, spices and other plant materials (Manganari y Oreopoulou, 1991; Tsuda et al., 1993; Frankel et al., 1997; Chen et al., 1998; Hall et al., 1998). Several substances including alcoholic extracts of different spices, paprika and rosemary, show good antioxidant activity. Rosemary extracts exhibited higher antioxidant effect compared to other natural extracts (Houlihan et al., 1984; Houlihan et al., 1985). According to Satue et al., (1995) antioxidant compounds extracted from virgin olive oil increased the oxidative stability of refined olive oil. Antioxidants present in virgin olive oil, contribute to its oxidative stability (Kiritsakis, 1998; Blekas y Boskou, 1998). Vegetable water, a main by-product of olive fruit processing, contains sufficient amount of polyphenols $(18-125 \mathrm{mg} / \mathrm{g})$, which may act as antioxidants and prevent lipid oxidation (Unal, 1994).

The present study was undertaken to gain knowledge on the effect of rosemary leaves and of vegetable water extracts on olive oil (blend of refined and virgin olive oil, 3 to 1) and sunflower oil, under accelerated oxidative conditions. 


\section{EXPERIMENTAL PART}

\subsection{Oils - Rosemary Leaves and Vegetable Water}

Refined olive oil and sunflower oil, obtained from a local market, was used in this study. Virgin olive oil was provided by a local producer. Parts three to one $(w / w)$ of refined and virgin olive oil were mixed and blend olive oil was formed. Rosemary leaves were collected from the garden of the Mediterranean Agronomic Institute of Chania (MAICh). The leaves were left to dry at room temperature. Vegetable water from a double phase decanter, from the olive oil mill of the Subtropical and Olive Trees Institute of Chania, was used.

\subsection{Preparation of Samples}

\subsubsection{Methanol Extracts of Rosemary Leaves}

The methanol phenolic extracts of rosemary were prepared according to the method proposed by $\mathrm{Wu}$ et al. (1982). $500 \mathrm{~g}$ of dried rosemary leaves were ground to pass through $0.5 \mathrm{~mm}$ sieve, and phenols were extracted with $3 \mathrm{~L}$ of methanol $(95 \%)$ at $60^{\circ} \mathrm{C}$ for $2 \mathrm{~h}$. The mixture was filtered and the residue was extracted again with $2 \mathrm{~L}$ of methanol. The combined filtrate was bleached with $100 \mathrm{~g}$ of active carbon for $15 \mathrm{~min}$, and then filtered to yield a light-brown filtrate. The methanol solution was concentrated to $300 \mathrm{ml}$ by a rotary evaporator and then filtered to remove any precipitates.

\subsubsection{Vegetable Water Extracts}

The vegetable water extracts were prepared according to the method proposed by Balice and Cera (1984). $50 \mathrm{ml}$ of vegetable water, were filtered through a Watman 41 filter paper and then acidified with $\mathrm{HCl}(\mathrm{pH}=2)$, and saturated with $\mathrm{NaCl}$. Then, 50 $\mathrm{ml}$ of ethyl acetate were added and the mixture was stirred for $10 \mathrm{~min}$. Ethyl acetate solution was dried over anhydrous sodium sulphate.

\subsubsection{Addition of Antioxidants to Oil Samples}

$100 \mathrm{~g}$ of each oil (blend olive oil and sunflower oil) was transferred to $250 \mathrm{~mL}$ flask and the exact amount of the phenol extract or the synthetic antioxidant was added to the oil. Methanol phenolic extracts and the synthetic antioxidant were added alone and in combinations as follows: $200 \mathrm{ppm}$ rosemary extract, $200 \mathrm{ppm}$ vegetable water extract, $100 \mathrm{ppm}$ rosemary extract $+100 \mathrm{ppm} \mathrm{BHA}, 100 \mathrm{ppm}$ vegetable water extract $+100 \mathrm{ppm} \mathrm{BHA}$ and 200 ppm BHA. After complete mixing, the solvent was evaporated at $55{ }^{\circ} \mathrm{C}$ under vacuum, in a rotary evaporator. The volume was completed with oil and the mixture was left to equilibrate.

\subsection{Oven Test}

Oil samples (50 g each) containing the additives were transferred into a series of capped transparent glasses and put in an oven at $63^{\circ} \mathrm{C}$. The peroxide value (PV) of the oil samples was periodically determined by the AOCS (1989) method.

\subsection{Conductivity Method}

The antioxidant activity of the tested additives was also determined using a Rancimat apparatus (Metrohm AG, CH-9100 Herisau, Switzerland) (Laubli and Bruttel, 1986). $3 \mathrm{~g}$ of oil samples were used. Temperature was set at $120^{\circ} \mathrm{C}$ and the flow rate at $20 \mathrm{~L} / \mathrm{h}$. The induction period was recorded automatically.

\subsection{Frying Process}

The frying process started 10 days after the additives were added to the oils. During the 10 days period all treated samples and the control were stirred occasionally for $20 \mathrm{~min}$. $350 \mathrm{~g}$ of potatoes were fried (French fries) in $900 \mathrm{~g}$ of oil at $180^{\circ} \mathrm{C}$ for 15 $\mathrm{min}$. The frying procedure was repeated eight times. The total frying lasted $120 \mathrm{~min} .30 \mathrm{~g}$ of oil sample was weighted after each frying and stored in the refrigerator until the time of analysis. Peroxide value and specific absorbance $\left(\mathrm{K}_{232}, \mathrm{~K}_{270}\right.$ and $\left.\Delta \mathrm{K}\right)$ measurements as described by Kiritsakis (1998) were conducted to measure the degree of oxidation. The phenol content of the oil samples was also determined during the study, by the Gutfinger (1981) method.

\subsection{Statistical Analysis}

The Statistical analysis was carried out using the LSD test and DUNCAN's Multiple Range test to evaluate the significant differences between the samples.

\section{RESULTS AND DISCUSSION}

\subsection{Evaluation of Additives by the Oven Test}

Table I shows the effect of methanol phenolic extracts on peroxide formation in oil samples when 
the oven test was used. In the control samples of blend olive oil, the PV was $77 \mathrm{meq} / \mathrm{kg}$ oil at 120 days, while the control samples of sunflower oil reached $85 \mathrm{meq} / \mathrm{kg}$ oil in 12 days. This was expected due to the faster oxidation (Chan et al., 1982) of the polyunsaturated sunflower oil and to the presence of natural antioxidants in blend olive oil, which act as potent antioxidants (Papadopoulos and Boskou, 1991). The relative inhibitory effect of the different additives in blend olive oil was in the following order: $200 \mathrm{ppm}$ rosemary extract $>100$ ppm rosemary extract +100 ppm BHA $>200$ ppm BHA. Neither 200 ppm vegetable water extract nor $100 \mathrm{ppm}$ vegetable water extract +100 ppm BHA improved the oxidative stability of the samples. Samples containing 200 ppm rosemary extract exhibited the highest oxidative stability for both oils. Manganari and Oreopoulou (1991) also found high antioxidant effect of rosemary extracts when tested in lard and in corn oil.

Table I

The effect of phenolic additives on peroxide formation in blend olive oil and in sunflower oil (Oven test at $63^{\circ} \mathrm{C}$ )

\begin{tabular}{|c|c|c|c|c|c|c|c|c|c|c|c|c|c|}
\hline \multirow{2}{*}{ Samples } & \multicolumn{13}{|c|}{ Number of days } \\
\hline & 0 & 3 & 6 & 9 & 12 & 15 & 30 & 45 & 60 & 75 & 90 & 105 & 120 \\
\hline BO Control & $3 a$ & & & & & $8 b$ & $16 c$ & $23 d$ & $33 e$ & $42 f$ & $50 \mathrm{~h}$ & $62 \mathrm{j}$ & $77 y$ \\
\hline $\mathrm{BO}+200 \mathrm{ppm} \mathrm{BHA}$ & $3 a$ & & & & & $6 a b$ & $12.5 \mathrm{c}$ & $17 d$ & $27 e$ & $36 f$ & $47 \mathrm{~h}$ & $59 j$ & $69 y$ \\
\hline \multicolumn{14}{|l|}{$\mathrm{BO}+100 \mathrm{ppm} \mathrm{Vw}$} \\
\hline + 100 ppm BHA & $3 a$ & & & & & $6 a$ & $10 \mathrm{c}$ & $16 d$ & $27 e$ & $36 f$ & $48 \mathrm{~h}$ & $60 \mathrm{j}$ & $73 y$ \\
\hline $\mathrm{BO}+200 \mathrm{ppm} \mathrm{Vw}$ & $3 a$ & & & & & $6 b$ & $12 c$ & $20 d$ & $31 \mathrm{e}$ & $41 f$ & $50 \mathrm{~h}$ & $62 j$ & $77 y$ \\
\hline \multicolumn{14}{|l|}{$\mathrm{BO}+100 \mathrm{ppm}$ Ros } \\
\hline + 100 ppm BHA & $3 a$ & & & & & $6 a b$ & $8 b$ & $12 \mathrm{c}$ & $19 d$ & $26 e$ & $35 f$ & $46 \mathrm{~h}$ & $57 j$ \\
\hline $\mathrm{BO}+200 \mathrm{ppm}$ Ros & $3 a$ & & & & & $5 a b$ & $7 \mathrm{~b}$ & $12 \mathrm{c}$ & $17 d$ & $24 e$ & $31 e$ & $37 f$ & $44 \mathrm{~h}$ \\
\hline So Control & $6 a$ & $18 b$ & $46 d$ & $56 e$ & $85 f$ & $119 j$ & & & & & & & \\
\hline $\mathrm{SO}+200 \mathrm{ppm} \mathrm{BHA}$ & $6 a$ & $11 b$ & $28 \mathrm{c}$ & $36 \mathrm{c}$ & $48 d$ & $62 e$ & & & & & & & \\
\hline \multicolumn{14}{|l|}{$\mathrm{SO}+100 \mathrm{ppm} \mathrm{Vw}$} \\
\hline + 100 ppm BHA & $6 a$ & $14 b$ & $33 c$ & $49 d$ & $71 f$ & $102 j$ & & & & & & & \\
\hline $\mathrm{SO}+200 \mathrm{ppm} \mathrm{Vw}$ & $6 a$ & $15 b$ & $40 \mathrm{~cd}$ & $52 \mathrm{de}$ & $79 f$ & $111 \mathrm{j}$ & & & & & & & \\
\hline \multicolumn{14}{|l|}{$\mathrm{SO}+100 \mathrm{ppm}$ Ros } \\
\hline + 100 ppm BHA & $6 a$ & $9 a$ & $11 a b$ & $16 b$ & $23 \mathrm{bc}$ & $33 c$ & & & & & & & \\
\hline $\mathrm{SO}+200 \mathrm{ppm}$ Ros & $6 a$ & $7 a$ & $8 a$ & $12 a b$ & $18 b$ & $25 b c$ & & & & & & & \\
\hline
\end{tabular}

Values with the same letter are not significantly different with Duncan's Multiple Range Test.

$\mathrm{BO}=$ Blend olive oil (mixture of refined olive oil with virgin olive oil, $3 / 1$ ).

SO = Sunflower oil.

$\mathrm{Vw}=$ Vegetable water extract.

Ros $=$ Rosemary extract. 


\subsection{Evaluation of Additives by the Conductivity Method}

Table II shows that the results recorded by the Rancimat apparatus were consistent with those obtained by the oven test (Tables I). The induction period for the control samples of blend olive oil and those of sunflower oil was 5.55 and $2.03 \mathrm{~h}$, respectively. Under these conditions, phenolic extracts increased the resistance of oil samples to oxidation. Vegetable water extract seemed to show similar antioxidant effect to BHA. Both oil samples containing $100 \mathrm{ppm}$ rosemary extract $+100 \mathrm{ppm}$ $\mathrm{BHA}$, or $200 \mathrm{ppm}$ rosemary extract showed longer induction period than oil samples containing the other additives (Table II). Blend olive oil containing $200 \mathrm{ppm}$ rosemary extract exhibited longer induction time $(11.2 \mathrm{~h})$ than sunflower oil samples $(3.25 \mathrm{~h})$ as compared to their respective controls.

Table II

The effect of phenolic additives on the oxidative stability of blend olive oil and sunflower oil as determined by the Rancimat apparatus at $120^{\circ} \mathrm{C}$

\begin{tabular}{|c|c|}
\hline Sample & Induction time (h) \\
\hline BO Control & 5.55 \\
\hline $\mathrm{BO}+200$ ppm BHA & 6.85 \\
\hline $\mathrm{BO}+100 \mathrm{ppm} \mathrm{Vw}+100 \mathrm{ppm} \mathrm{BHA}$ & 6.65 \\
\hline $\mathrm{BO}+200 \mathrm{ppm} \mathrm{Vw}$ & 6.37 \\
\hline $\mathrm{BO}+100$ ppm Ros + 100 ppm BHA & 8.78 \\
\hline $\mathrm{BO}+200 \mathrm{ppm}$ Ros & 11.2 \\
\hline SO Control & 2.03 \\
\hline $\mathrm{SO}+200 \mathrm{ppm} \mathrm{BHA}$ & 2.12 \\
\hline $\mathrm{SO}+100 \mathrm{ppm} \mathrm{Vw}+100 \mathrm{ppm} \mathrm{BHA}$ & 2.08 \\
\hline $\mathrm{SO}+200 \mathrm{ppm} \mathrm{Vw}$ & 2.15 \\
\hline $\mathrm{SO}+100 \mathrm{ppm}$ Ros + $100 \mathrm{ppm} \mathrm{BHA}$ & 2.73 \\
\hline $\mathrm{SO}+200 \mathrm{ppm}$ Ros & 3.25 \\
\hline
\end{tabular}

See Table I for abbreviations.

\subsection{Evaluation of Additives during the Frying Process}

Table III shows that $K_{232}$ values for both oils increased with the frying time indicating the formation of conjugated hydroperoxides. At the end of the frying process the $K_{232}$ values for blend olive oil containing no additives were lower than those of the control sunflower oil. The blend olive oil had initial $\mathrm{K}_{232}$ value 2.64 which increased to 4.30 by the end of frying. In contrast, sunflower oil had an initial value of 3.72 which increased to 10.11 (Table III). Blend olive oil samples containing 200 ppm rosemary extract showed the lowest $K_{232}$ value (3.92) by the end of frying. Our results agree with others (Manganari y Oreopoulou, 1991; Houlihan et al., 1984).

Table III

Absorbance Values $\left(\mathrm{K}_{232}\right)$ of blend olive oil and sunflower oil treated with phenolic additives and subjected to frying process

\begin{tabular}{|c|c|c|c|c|c|}
\hline \multirow{2}{*}{ Samples } & \multicolumn{5}{|c|}{ Number of Fryings } \\
\hline & 0 & 2 & 4 & 6 & 8 \\
\hline BO Control & $2.64 a$ & $3.19 \mathrm{c}$ & $3.65 d$ & $3.94 e$ & $4.3 f$ \\
\hline $\mathrm{BO}+100 \mathrm{ppm} \mathrm{Vw}+100 \mathrm{ppm} \mathrm{BHA}$ & $2.64 a$ & $3.30 \mathrm{c}$ & $3.34 \mathrm{c}$ & $3.78 \mathrm{~d}$ & $4.12 f$ \\
\hline $\mathrm{BO}+200 \mathrm{ppm} \mathrm{Vw}$ & $2.9 b$ & $2.9 \mathrm{~b}$ & $3.42 \mathrm{c}$ & $3.56 \mathrm{c}$ & $4.04 \mathrm{et}$ \\
\hline $\mathrm{BO}+100 \mathrm{ppm}$ Ros $+100 \mathrm{ppm} \mathrm{BHA}$ & $2.62 a$ & $3.18 \mathrm{bc}$ & $3.64 d$ & $3.9 e$ & $4.18 f$ \\
\hline $\mathrm{BO}+200 \mathrm{ppm}$ Ros & $2.70 \mathrm{a}$ & $3.13 b c$ & $3.40 \mathrm{c}$ & $3.7 d$ & $3.92 \mathrm{e}$ \\
\hline SO Control & $3.72 \mathrm{a}$ & $6.51 b$ & $8.26 \mathrm{c}$ & $9.22 \mathrm{~d}$ & $10.1 \mathrm{e}$ \\
\hline $\mathrm{SO}+100 \mathrm{ppm} \mathrm{Vw}+100 \mathrm{ppm} \mathrm{BHA}$ & $3.77 a$ & $6.76 \mathrm{~b}$ & $8.36 \mathrm{c}$ & $9.28 \mathrm{~d}$ & $10.2 \mathrm{e}$ \\
\hline $\mathrm{SO}+200 \mathrm{ppm} \mathrm{Vw}$ & $3.75 a$ & $6.35 b$ & $7.73 \mathrm{~b}$ & $8.42 \mathrm{c}$ & $9.38 \mathrm{~d}$ \\
\hline $\mathrm{SO}+100 \mathrm{ppm}$ Ros $+100 \mathrm{ppm} \mathrm{BHA}$ & $3.72 a$ & $5.51 \mathrm{~b}$ & $6.57 \mathrm{~b}$ & $7.02 \mathrm{~b}$ & $7.51 \mathrm{c}$ \\
\hline $\mathrm{SO}+200 \mathrm{ppm}$ Ros & $3.74 a$ & $5.41 \mathrm{~b}$ & $6.26 \mathrm{~b}$ & $6.98 \mathrm{~b}$ & $7.34 \mathrm{c}$ \\
\hline
\end{tabular}

See Table I for abbreviations.

Values with the same letter are not significantly different with Duncan's Multiple Range Test.

The $K_{270}$ values increased significantly in both oils with frying time (Table IV), indicating a continuous formation of secondary oxidation products (Hamilton, 1989; Kiritsakis,1998). The initial $K_{270}$ value for control samples of blend olive oil was 0.81 and increased to 1.19 by the end of frying. However, the control samples of the sunflower oil had initial value 2.43 which increased to 3.55 , indicating the formation of more decomposition oxidation products in sunflower oil than in blend olive oil. The latter contains more oleic and less linoleic (Kiritsakis, 1998) and according to Nawar (1985) thermal oxidation of linoleic gives higher amount of decomposition products than oleic. However, samples containing $100 \mathrm{ppm}$ rosemary extract $+100 \mathrm{ppm}$ $\mathrm{BHA}$, or $200 \mathrm{ppm}$ rosemary extract showed the highest absorbance at $270 \mathrm{~nm}$ at the end of frying. These results were inconsistent with $\mathrm{K}_{232}$ values and indicate that the measurement of UV absorbance is not the best parameter to evaluate oil alterations during frying. Frying temperature and food humidity may affect the values. $\Delta \mathrm{K}$ values did not provide additional information since values increased but not significantly in both oils with frying time (Table V). 
Table IV

\section{Absorbance Values $\left(K_{270}\right)$ of blend olive oil and sunflower oil treated with phenolic additives and subjected to frying process}

\begin{tabular}{|c|c|c|c|c|c|}
\hline \multirow{2}{*}{ Samples } & \multicolumn{5}{|c|}{ Number of Fryings } \\
\hline & 0 & 2 & 4 & 6 & 8 \\
\hline BO Control & $0.81 a$ & $1.00 \mathrm{a}$ & $1.18 \mathrm{c}$ & $1.18 \mathrm{c}$ & $1.19 \mathrm{c}$ \\
\hline $\mathrm{BO}+100 \mathrm{ppm} V \mathrm{~W}+100 \mathrm{ppm} \mathrm{BHA}$ & $0.89 a$ & $1.00 \mathrm{~b}$ & $1.09 \mathrm{c}$ & $1.16 \mathrm{c}$ & $1.20 d$ \\
\hline $\mathrm{BO}+200 \mathrm{ppm} \mathrm{Vw}$ & $0.90 \mathrm{a}$ & $0.96 \mathrm{~b}$ & $1.08 \mathrm{c}$ & $1.11 \mathrm{c}$ & $1.19 \mathrm{c}$ \\
\hline $\mathrm{BO}+100 \mathrm{ppm}$ Ros $+100 \mathrm{ppm} \mathrm{BHA}$ & $0.97 a$ & $1.07 \mathrm{c}$ & $1.27 d$ & $1.30 \mathrm{~d}$ & $1.33 d$ \\
\hline $\mathrm{BO}+200 \mathrm{ppm}$ Ros & $0.99 a$ & $1.07 \mathrm{c}$ & $1.25 d$ & $1.45 \mathrm{e}$ & $1.54 f$ \\
\hline So Control & $2.43 a$ & $2.91 b$ & $3.42 \mathrm{c}$ & $3.47 \mathrm{c}$ & $3.55 d$ \\
\hline $\mathrm{SO}+100 \mathrm{ppm} \mathrm{Vw}+100 \mathrm{ppm} \mathrm{BHA}$ & $2.67 a$ & $2.95 b$ & $3.45 \mathrm{c}$ & $3.48 \mathrm{c}$ & $3.53 d$ \\
\hline $\mathrm{SO}+200 \mathrm{ppm} \mathrm{Vw}$ & $2.71 \mathrm{a}$ & $2.92 b$ & $3.41 \mathrm{c}$ & $3.44 \mathrm{c}$ & $3.46 \mathrm{c}$ \\
\hline $\mathrm{SO}+100 \mathrm{ppm}$ Ros + $100 \mathrm{ppm}$ BHA & $2.43 a$ & $2.90 \mathrm{~b}$ & $3.44 c$ & $3.46 \mathrm{c}$ & $3.59 d$ \\
\hline $\mathrm{SO}+200 \mathrm{ppm}$ Ros & $2.45 a$ & $2.96 \mathrm{~b}$ & $3.45 c$ & $3.47 c$ & $3.65 \mathrm{e}$ \\
\hline
\end{tabular}

See Table I for abbreviations.

Values with the same letter are not significantly different with Duncan's Multiple Range Test.

\section{Table V}

Absorbance Values $(\Delta K)$ of blend olive oil and sunflower oil treated with phenolic additives and subjected to the frying process

\begin{tabular}{|c|c|c|c|c|c|}
\hline \multirow{2}{*}{ Samples } & \multicolumn{5}{|c|}{ Number of Fryings } \\
\hline & 0 & 2 & 4 & 6 & 8 \\
\hline BO Control & $0.10 \mathrm{a}$ & $0.10 \mathrm{a}$ & $0.12 \mathrm{a}$ & $0.11 \mathrm{a}$ & $0.10 \mathrm{a}$ \\
\hline $\mathrm{BO}+100 \mathrm{ppm} \mathrm{Vw}+100 \mathrm{ppm} \mathrm{BHA}$ & $0.09 a$ & $0.10 \mathrm{a}$ & $0.12 a$ & $0.11 \mathrm{a}$ & $0.11 \mathrm{a}$ \\
\hline $\mathrm{BO}+200 \mathrm{ppm} \mathrm{Vw}$ & $0.09 a$ & $0.11 a$ & $0.11 a$ & $0.11 a$ & $0.10 a$ \\
\hline $\mathrm{BO}+100 \mathrm{ppm}$ Ros $+100 \mathrm{ppm}$ BHA & $0.09 a$ & $0.11 a$ & $0.13 a$ & $0.13 a$ & $0.13 a$ \\
\hline $\mathrm{BO}+200 \mathrm{ppm}$ Ros & $0.10 \mathrm{a}$ & $0.11 a$ & $0.13 b$ & $0.13 \mathrm{a}$ & $0.14 \mathrm{a}$ \\
\hline So Control & $0.41 \mathrm{a}$ & $0.42 a$ & $0.48 a$ & $0.43 a$ & $0.44 a$ \\
\hline $\mathrm{SO}+100 \mathrm{ppm} \mathrm{Vw}+100 \mathrm{ppm} \mathrm{BHA}$ & $0.42 a$ & $0.43 a$ & $0.47 \mathrm{~b}$ & $0.45 \mathrm{a}$ & $0.44 a$ \\
\hline $\mathrm{SO}+200 \mathrm{ppm} \mathrm{Vw}$ & $0.42 a$ & $0.45 \mathrm{a}$ & $0.44 a$ & $0.48 \mathrm{~b}$ & $0.44 a$ \\
\hline $\mathrm{SO}+100 \mathrm{ppm}$ Ros $+100 \mathrm{ppm}$ BHA & $0.43 a$ & $0.42 a$ & $0.46 \mathrm{a}$ & $0.47 a$ & $0.47 a$ \\
\hline $\mathrm{SO}+200 \mathrm{ppm}$ Ros & $0.43 a$ & $0.43 a$ & $0.49 a$ & $0.51 b$ & $0.54 \mathrm{~b}$ \\
\hline
\end{tabular}

See Table I for abbreviations.

Values with the same letter are not significantly different with Duncan's Multiple Range Test.

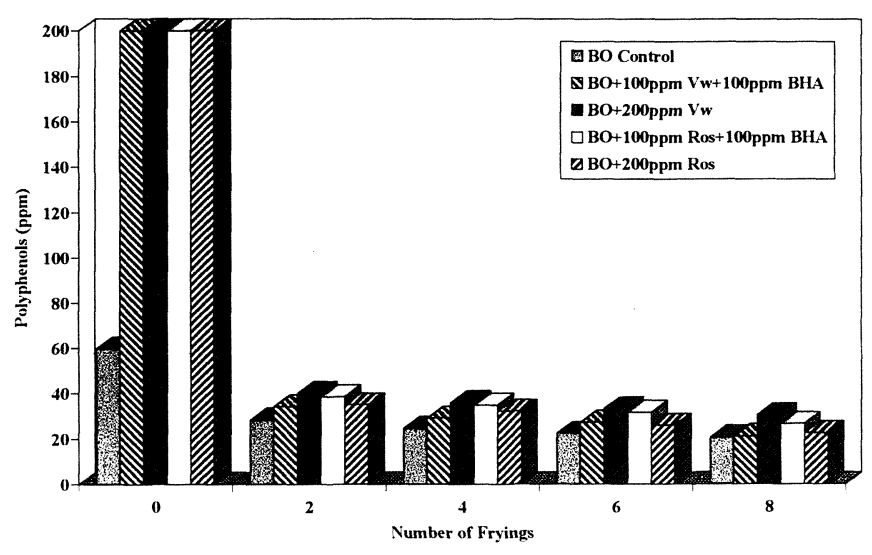

Figure 1

Changes in the polyphenol content of blend olive oil during the frying process

(Abbreviations as in Table I)

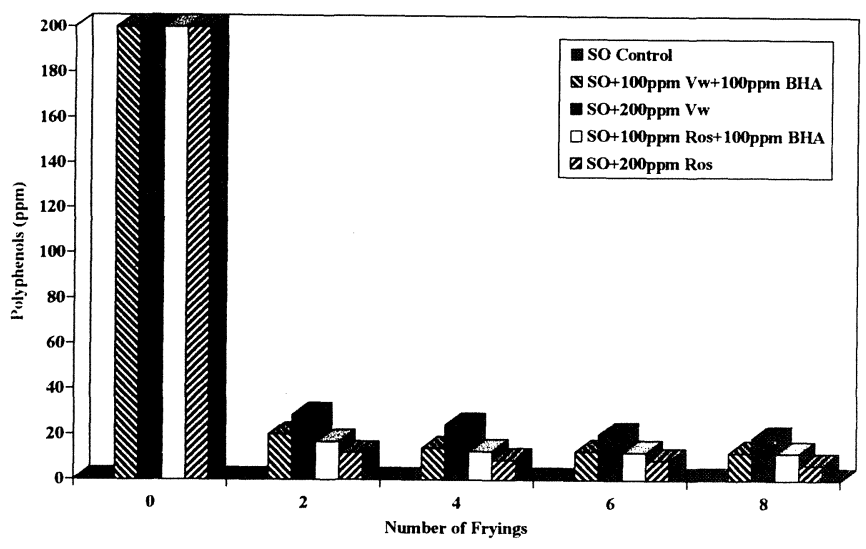

Figure 2

Changes in the polyphenol content of sunflower oil during the frying process

(Abbreviations as in Table I)

In both (blend olive oil and sunflower) oils a significant decrease in polyphenol content with the time was observed (Figs. 1, 2), due to the effect of frying temperature (Loliger, 1989). Natural polyphenols $(60 \mathrm{ppm})$ present in the control samples of blend olive oil (control samples of sunflower oil contained no polyphenols), were more resistant to high temperature than polyphenols from the antioxidants extracts. Among the added extracts, those from vegetable water showed higher resistance. Samples to which $200 \mathrm{ppm}$ polyphenols from the vegetable water were added, contained at the end of the experiment, the higher amount of polyphenols, which was $30.5 \mathrm{ppm}$ and $18.6 \mathrm{ppm}$ for blend olive oil 
and sunflower oil respectively. The presence of lower amount of polyphenols, at the end of the experiment, in samples to which 200 ppm of rosemary extract extract was added compared to those containing 200 ppm vegetable water extract (Figs. 1, 2) may explains the higher antioxidant effect of rosemary extracts. Polyphenols were probably used and the oxidation was retarded.

In conclusion, under accelerated oxidation conditions (63 ${ }^{\circ} \mathrm{C}$ in oven and $120^{\circ} \mathrm{C}$ in Rancimat), methanol phenolic extracts of rosemary leaves and vegetable water exhibited antioxidant activity. Better results were obtained from rosemary than vegetable water.

\section{ACKNOWLEDGEMENTS}

The authors express their appreciation to $A$. Nikolaidis, director of the Mediterranean Agronomic Institute of Chania (MAICh), Greece, where this work was conducted and to $\mathrm{Ch}$. Petrakis for technical assistance.

\section{BIBLIOGRAPHY}

American Oil Chemists' Society (1989)._-Official and tentative methods (Fourth edition)".-Champaign, (Illinois), USA.

Balice, V. y Cera, O. (1984).-—Acidic phenolic fraction of the olive vegetable water determined by a gas chromatographic method".-Grasas y Aceites, 35, 178-180.

Blekas, G. y Boskou, D. (1998).- - «Antioxidative activity of 3,4-dihydroxyphenylacetic acid and $\alpha$-tocopherol on the triglyceride matrix of olive oil. Effect of acidity».-Grasas y Aceites, 49, 34-37.

Chan, H. S., Coxon, D. T., Peers, K. E. y Price, K. R. (1982)."Oxidative reactions of unsaturated lipids".-Food Chem., 9, 21-34.

Chen, Z. Y., Wang, L. Y., Chan, P. T., Zhang, Z., Chung, H. $Y$ y Liang C. (1998). - «Antioxidative activity of green catechin extract compared with that of rosemary extract».-J. Am. Oil Chem. Soc., 75, 1141-1145.

Frankel, E. N., Huang, S.W. y Aeschbach, R. (1997)."Antioxidant activity of green teas in different lipid systems".-J. Am. Oil Chem. Soc, 74, 1309-1315.

Gutfinger, J. (1981).- «Polyphenols in olive oil».-J. Am. Oil Chem. Soc., 58, 966-986.

Hall, C. A., Cuppett, S. L. y Dussault, P. (1998)."Hydrogen-donating mechanism of rosmariquinone, an antioxidant found in rosemary".-J. Am. Oil Chem. Soc., $75,1147-1154$.

Hamilton, R. J. (1989).- - «The Chemistry of Rancidity in Foods".-Rancidity in Foods, 2nd edition, 1-22. Allen, J. C. and Hamilton, R. J., (Ed). Elsevier Science Publishers Ltd., Amsterdam, The Netherlands.

Houlihan, C. M., Ho, C.T. y Chang S. S. (1984)."Elucidation of the chemical structure of a novel antioxidants: Rosmaridiphenol, isolated from rosemary".-J. Am. Oil Chem. Soc., 61, 1036-1039.

Houlihan, C. M., Ho, C. T. y Chang, S. S. (1985).- «The structure of Rosemariquinone. A new antioxidant isolated from Rosmarinus OfficinalisL.».-J. Am. Oil Chem. Soc., 62, 96-98.

Kiritsakis, A. (1998).- "Olive oil: From the tree to the table".-Food and Nutrition Press, 2nd Ed. Inc, Trumbull (Conn), USA.

Laubli, M. W. y Bruttel, P. B. (1986).-«Determination of the oxidation stability of fats and oils: Comparison between the active oxygen method (AOCS Cd 12-57) and the rancimat».-J. Am. Oil Chem. Soc., 63 792-795

Loliger, J. (1989).— «Natural antioxidants in Rancidity in foods".-105-124, Allen, J. C. and Hamilton, R. J. (Ed). $2^{\text {nd }}$ edition. Elsevier Science Publishers Ltd., Amsterdam, The Netherlands.

Manganari, F. y Oreopoulou, V. (1991).- «Combined effect of some plant extracts and BHA on lipid oxidation".-Riv. Ital. Sost. Grasse, LXVIII, 305-308.

Nawar, W. W. (1985).- «Chemistry of thermal oxidation of lipids in Flavor Chemistry of Fats and oils".-39-60. D. B. Min, y T. H. Smouse, (Ed) Am Oil Chem. Soc, Champaign, (Illinois), USA

Papadopoulos, G. y Boskou, D (1991).— -Antioxidant effect of natural phenols on olive oil».-J. Am. Oil Chem. Soc., 68, 669-671.

Satue, M. T., Huang, S. W. y Frankel, E. N. (1995).«Effect of natural antioxidants in virgin olive oil on oxidative stability of refined, bleached and deodorized olive oil».-J. Am. Oil Chem. Soc., 72, 1131-1137.

Sherwin, E. R. (1990).- «Antioxidants in Food Aditives».Branen, A. L., Davidson, P. M. y Salminen, S. (Ed). Marcel-Dekker, Inc. New York, USA.

Tsuda, T., Osawa, T., Nakayama, T., Kawakishi, S. y Ohshima, K. (1993).- -Antioxidant activity of pea bean (Phaseolus vulgaris 1.) extract».-J. Am. Oil Chem. Soc., 70, 909-913.

Unal, K. M. (1994).- - Total polyphenols, O-diphenols and phenolic acids in olive pomace and olive vegetation water".-Olivae, 51, 134-135.

Wu, J. W., Lee, H., Ho, C. T. y Chang S. S. (1982)."Elucidation of the chemical structure of natural antioxidants isolated from Rosemary".-J. Am. Oil Chem Soc., 59, 339-345. 